Article

\title{
Environmental Consciousness of Entrepreneurs in Ghana: How Do Entrepreneur Types, Demographic Characteristics and Product Competitiveness Count?
}

\author{
Simon Bawakyillenuo * and Innocent Sefa Komla Agbelie
}

check for updates

Citation: Bawakyillenuo, S.; Agbelie, I.S.K. Environmental Consciousness of Entrepreneurs in Ghana: How Do Entrepreneur Types, Demographic Characteristics and Product Competitiveness Count? Sustainability 2021, 13, 9139. https://doi.org/10.3390/su13169139

Academic Editors: João Carlos

Correia Leitão, Oliver Mauroner and Tomonobu Senjyu

Received: 2 July 2021

Accepted: 11 August 2021

Published: 16 August 2021

Publisher's Note: MDPI stays neutral with regard to jurisdictional claims in published maps and institutional affiliations.

Copyright: (c) 2021 by the authors. Licensee MDPI, Basel, Switzerland. This article is an open access article distributed under the terms and conditions of the Creative Commons Attribution (CC BY) license (https:// creativecommons.org/licenses/by/ $4.0 /)$.
Institute of Statistical, Social and Economic Research (ISSER), University of Ghana, Legon, Accra LG 74, Ghana; sefinno@gmail.com

* Correspondence: sbawakyillenuo@ug.edu.gh

\begin{abstract}
Businesses are believed to be partly responsible for upsetting the balance of local biodiversity through activities that degrade the environment. Critically, entrepreneurship is increasingly being cited as a key sector that can bring about sustainable transformation in production and distribution. Ghana's total entrepreneurial activity rate is estimated at $37 \%$, with businesses operating unsustainably. Meanwhile, little has been explored empirically on the factors that influence businesses' sensitivity to the environment in Ghana. Using the 2013 GEM data in estimating seven different logic regression models coupled with a qualitative analysis, this paper fills the gap by investigating how the demographic and entrepreneurial characteristics of entrepreneurs in Ghana influence their environmental consciousness. The empirical evidence suggests that education fosters environmental consciousness, while owner-manager and female entrepreneurs as well as rural locality entrepreneurs in Ghana tend to be more environmentally sensitive. The qualitative data also revealed general concerns for the environment as motivating factors for entrepreneurs to be more environmentally conscious. The findings therefore draw attention to the inadequate focus on green entrepreneurship in Ghana. Embarking on educational campaigns to promote the adherence to environmental regulations by all businesses, especially those in urban areas, could help build a robust eco-preneurship landscape in Ghana.
\end{abstract}

Keywords: entrepreneurship; eco-preneur; environmental consciousness; Ghana

\section{Introduction}

The current trend of society's consumption of natural resources, especially in the area of energy production, requires a fundamental transformation if the world is to make meaningful progress in curtailing ecosystem degradation and global climate change [1]. A few scholars consider the business community partly responsible for many of these environmental problems [2-5]. For instance, the mining industry is known to cause land, water and air pollution in and around mining communities in Ghana: sachet and bottled water companies create plastic wastes, which choke drainage systems across cities in Ghana, and the tourism industry can affect the balance of the local biodiversity, landscape and heritage [6,7]. In effect, entrepreneurship is increasingly being cited as a key sector that can bring about sustainable transformation in production and distribution processes, once the appropriate enabling factors are in place. Academic discourse on sustainable development within the mainstream entrepreneurship literature has gained recognition over time, with many studies exploring various channels through which environmental consciousness can be nurtured among entrepreneurs.

Entrepreneurs have long been recognized as critical stakeholders that can tap into various opportunities associated with societal needs. Driven particularly by the need for independence [8-10] and crucially, by the opportunity for earning income and employment [11,12], entrepreneurs play indispensable roles in socio-economic development, 
particularly in developing countries. For instance, the estimated total entrepreneurial activity (TEA) rates in 2012 (TEA rate is the percentage of individuals in an economy who are in the process of starting or already running a new business) were generally highest in factor-driven economies (Economies with early stages of economic development, typically with a large agricultural sector and where the economy is largely dependent on the extraction of natural resources) such as Angola, Botswana, Ethiopia, Ghana, Malawi, Nigeria, Uganda and Zambia [13]. In Ghana, the TEA rate was estimated at 37\%, which implies that while many people were already involved in certain kinds of entrepreneurial activities, many more who had the intention of starting a business contributed to the yearly number. Many of these entrepreneurs tend to be younger with comparatively low educational levels, have low prospects for future jobs, low innovation level and often trade in identical goods and services in a perfectly competitive market [13]. These socio-demographic characteristics could be ascribed to the unsustainable production and distribution processes in the production sectors in Ghana. Additionally, entrepreneurial activities in Ghana are highly unregulated and informally structured such that almost every household engages in an activity often regarded by many as "a business". Undeniably, these businesses have contributed to the generation of filth, which has engulfed most cities in the country, thereby creating sanitation problems [14].

The environmental consciousness of the entrepreneur in Ghana, therefore, immediately becomes a critical subject for discussion, raising questions such as how consciously are entrepreneurs regarding the environment in which they operate? How are entrepreneurs' motives aligned to environmental sustainability? What motivates entrepreneurs to be more sensitive to their environments based on the products and services they render? Little has been done empirically to understand the operations of enterprises in the context of these questions in Ghana and this study seeks to fill such gaps. Guided by these questions, the researchers sought to gain empirical understanding of the demographic and motivational characteristics that determine the environmental consciousness of entrepreneurs in Ghana.

\section{The Entrepreneurial Landscape of Ghana}

In Ghana, there is a large pool of potential entrepreneurs with highly aware of opportunities and their own capabilities for starting a business, coupled with low fear of failure [13]. Many Ghanaians consider entrepreneurship to be a good career choice. The overall TEA rate in Ghana was estimated at 37\% as of 2012 [13]. Out of that, about 28\% of the entrepreneurs were driven by necessity (i.e., pushed into starting a business because they had no other choice and no other source of income), while $51 \%$ were driven by opportunities (i.e., pulled into entrepreneurship by the opportunity they perceived and chose to pursue). According to the Ghana Statistical Service, the unemployment rate was estimated around 5.3\% in 2010 and youth unemployment stood at 8\% in 2017 [15]. The unemployment situation could explain the necessity-driven entrepreneurship in Ghana where people saw a business start-up as an escape route from the unemployment trap. Owner-manager entrepreneurs (Owner-manager entrepreneurs are those who, alone or with others are owners of a business they helped established and have paid salaries for more than three months) dominate nascent entrepreneurs (Nascent entrepreneurs are those who have taken steps to start a new business, but have not yet paid salaries or wages for more than three months) in Ghana with a proportion of about $87 \%$ (Table 1). Female entrepreneurs are slightly higher in number (54\%), while there is an almost equal proportion of youth and adult entrepreneurs in Ghana. In terms of education, the majority of both nascent and owner-manager entrepreneurs have completed elementary, middle or second cycle education (Table 1 ).

There are various legislative instruments that guide the establishment and operation of businesses in Ghana to ensure safe and transparent business environments. The Environmental Protection Agency (EPA) is tasked with issuing the necessary environmental permits to companies. Currently, however, the unsustainable operations of businesses in Ghana (especially in big cities such as Accra, Kumasi, Tema and Cape Coast) suggest 
non-compliance with the EPA's environmental laws and regulations, as well as enforcement deficiencies. Generally, the state of environmental entrepreneurship in Ghana is predominantly a state-led developmental strategy [16], with most of the innovations taking place in the agro-processing subsector [17]. There are other private players whose competitive business activities and profit-driven motives have degraded the environment, costing the country some $10 \%$ of its gross domestic product (GDP) annually [18]. Green entrepreneurship is seen as a vital vehicle to addressing these challenges and eradicating poverty in Ghana [18,19].

Table 1. Demographic characteristics of entrepreneurs in Ghana (\%).

\begin{tabular}{lccc}
\hline \multirow{2}{*}{ Demographics } & \multicolumn{2}{c}{ Entrepreneur Type } & \multirow{2}{*}{ Total Sample } \\
\cline { 2 - 3 } & Nascent & Owner-Manager & \\
\hline Gender & & & 46.1 \\
\hline Male & 50 & 45.5 & 53.9 \\
Female & 50 & 54.5 & \\
\hline Youth/Adult prop & & & 49.2 \\
\hline Youth & 61.7 & 47.3 & 50.8 \\
Adult & 38.3 & 52.7 & 37.3 \\
\hline Education & & & 57.3 \\
\hline No education & 28.6 & 38.6 & 5.4 \\
Fairly educated & 61.5 & 56.7 & \\
Highly educated & 9.9 & 4.7 & \\
\hline Total & 13.0 & 87.0 & \\
\hline Source: GEM Survey, 2012. & & & \\
\hline
\end{tabular}

\section{The Concept of Green Entrepreneurship and Its Drivers}

Entrepreneurs are expected to bring about change and new opportunities, not just for themselves but for the community they belong to as well. Schaper regards entrepreneurs as agents of "creative destruction", completely transforming old and accepted modes of doing things through taking risks required to convert those ideas into realities [20]. On the other hand, green entrepreneurship [21,22], which is also sometimes referred to as eco-preneurship [14,23-25] or sustainable entrepreneurship [26], can be viewed as an offshoot of sustainable development (SD). Defined as "development that meets the needs of the present generation without compromising the ability of future generations to meet their own needs" [27] (p. 43), SD places social and environmental objectives on equal footing with economic objectives, the so-called "triple bottom line". Steadily, sustainability has become a mainstay of corporate strategy, hence, the proliferation of the creation of an executive "sustainability unit" by most firms [1]. In many circles, the term "corporate sustainability" has become synonymous to "corporate social responsibility" [1].

Green entrepreneurship is a new branch of entrepreneurship, which fuses environmentalism with entrepreneurial spirit, with the potential to move toward a recognized ecological society [28,29]. The term has no universally accepted definition, with scholars giving their own operational definitions and interpretations. Ref. [30] sees green entrepreneurs as those who practice modern green businesses through creative and innovative competencies. Ref. [31] also describes green entrepreneurship as a revolutionary solution to the current social, economic and environmental challenges, while [32] regards the concept as involving radical thinkers who can salvage the sociological landscape from environmental menaces.

The green entrepreneurship concept has been widely accepted by the business world and is gradually being integrated into business models. However, the concept has created a "managerial dilemma". According to [33,34], established businesses face the dilemma of whether to comply with environmental regulations and deal with the potential economic 
impacts by adopting some type of environmental management practices or pay the fines and taxes, provided that these costs are less than the cost of compliance. In the case of new entrepreneurs, the dilemma may be to start up a new business in a sector with a rigorous or sloppy environmental policy regime, to engage in an innovative sector associated with environmental resources (e.g., ecotourism) or in a conventional sector. Ref. [35] concludes that entrepreneurs are better positioned to create environmental benefits out of market imperfection while simultaneously reaping economic gains. Therefore, practicing green entrepreneurship could be classified into two key subcategories: established companies that adopt environmental management practices or cleaner production processes and new business start-ups based on natural and ecological resources such as solar energy companies and ecotourism [34].

\section{Drivers of Green Entrepreneurship-A Review}

Entrepreneurs are believed to be problem solvers who can apply innovation and critical thinking in addressing challenges. They are believed to be capable of finding solutions to environmental degradation rather than being the cause of it [36]. However, many businesses have continued to engage in "business-as-usual" practices driven by profit maximization motives [2], creating more environmental challenges than opportunities $[8,37]$. Many earlier studies have focused on how large firms can practicalize eco-preneurship in their operations [38,39]. Very few studies have focused on small and medium-sized green entrepreneurs [20,38,40]. Ref. [20] asserts that the importance of small and medium-sized enterprises is usually overlooked. Literature points to the fact that though SME owners mostly agree with generic environmental protection, they are generally more reactive in their adoption of green business models due to their limited resources, compared to corporations [8]. Considering firms of all sizes then, what factors have been known empirically to drive eco-preneurship in the business world?

The traditional belief that entrepreneurs cannot be environmentally aware, or do not care to be, is quickly becoming obsolete [41,42]. According to [9], entrepreneurial activities, which include eco-preneurship, social entrepreneurship, institutional entrepreneurship and sustainable entrepreneurship, are driven by personal motivations. The desire to maximize economic gains [43] and improve self-evaluation [9], self-efficacy [44] and confidence [45] is included as one of the motivational factors behind green entrepreneurship so that the ecosystem is sustained and sustainable development is guaranteed [46]. Ref. [47] found organic farmers in Pakistan to be conscious of both the environment and health of their activities. Accordingly, the adequate knowledge and skills, social inspiration, an available market, good production conditions, a strong personality and sense of ownership are important for an entrepreneur to become an eco-preneur. Ref. [48] also surveyed 1562 respondents in mainland China on sustainable entrepreneurship in the digital era. They found personal innovativeness - measured by education and technology trialabilityto significantly impact the intention of individuals toward green entrepreneurship.

Ref. [49] studied individuals who were concerned with environmental and societal issues and could potentially be interested in supporting initiatives and forming businesses that support sustainable development. They anchored their study within the entrepreneurship and sustainable development discourse, and used large-scale survey data to provide empirical insights into how sustainability orientation and entrepreneurial intentions are related. They hypothesized a positive relationship between an individual's sustainability orientation and entrepreneurial intention, but that business experience would negatively influence this relationship. Using data collected from students and alumni from science, engineering and business programs at three European universities, they applied ordinal probit models and found support for these hypotheses. Similarly, Ref. [50] developed a model of the conditions that foster the emergence of sustainable entrepreneurs versus traditional entrepreneurs. They argued that early in the transformation of an industry toward sustainability, new entrants are more likely to pursue sustainability opportunities. Eventually, existing firms respond to the new entrants by adopting sustainability practices. 
Ultimately, both the new entrants and existing ones co-evolve, creating incentives and competitive positions that allow them to survive. The study concluded that progress in creating sustainable industries and economies will rely on an interplay of entrepreneurial entry and transformation of incumbent players.

Ref. [51] studied a number of cases of entrepreneurial cooperation ranging from environmental tourism to organic labeling, and argued that green entrepreneurs may require institutional structures that go well beyond the standard-setting coalitions customary in many nascent industries. Accordingly, a green enterprise should devote some effort to generating communal institutions to improve the competitiveness of sustainable behaviors. In a related study, Ref. [52] explored a variety of private and public factors that influenced state-level solar entrepreneurship in the U.S solar energy sector between 1999 and 2006. They found social norms that were favorable to sustainability objectives to partially predict higher levels of entrepreneurship in the solar energy sector. Refs. [31,44,53] confirmed the importance of institutional structure and formal and informal networks in determining the green entrepreneurship landscape. The study of [54] goes beyond institutional structures to emphasize the influence of location and economic benefits as key determinants of green entrepreneurship in Malaysia.

\section{Materials and Methods}

This section discusses the methods and data used for the study, starting with the conceptual framework that underpins the construction of the theoretical model discussed in subsequent subsections. The variables of interest, informed by the conceptual framework, the types and availability of data, are also discussed in this section.

\subsection{Conceptual Framework-Determinants of Environmentally Conscious Entrepreneurs}

The study was anchored within the broad frames of supply and demand of ecopreneurship. The supply side involves the suppliers of environmental services within any business supply chain. The foundation of the determinants of these suppliers' environmental consciousness is found in the Consumer Green Purchase Framework (CGPF) developed by [55]. This framework (CGPF) was considered appropriate for this study because it interlinks the dependent variable with the mediating and independent variables that are of interest to the study. The CGPF suggests what a firm owner needs to look for prior to venturing into any potential market. For a firm to remain in business, the CGPF encourages entrepreneurs to strongly consider consumers' reaction and taste toward products and services they offer. This is because the inability to fully integrate consumers' reactions into managerial decisions can lead to suboptimal production of the firm and subsequently, less than expected profit margins.

Consumers are becoming more sensitive and selective in what they buy or consume [56,57]. Therefore, consumers are more mindful of the consumption of certain products that are harmful either to their health or the environment. Accordingly, the CGPF suggests that the environmental consciousness of consumers should form the basis for any environmentally conscious entrepreneur (Figure 1). The attitudinal change of consumers should give indications to entrepreneurs about the need to reform their production line, hence it is expected that innovative and creative entrepreneurs will see this as an opportunity and subsequently venture into products, services or production methods that are environmentally friendly. The determinants of consumers' green purchasing behavior could, thus, automatically determine the environmental consciousness of entrepreneurs (Figure 1). 


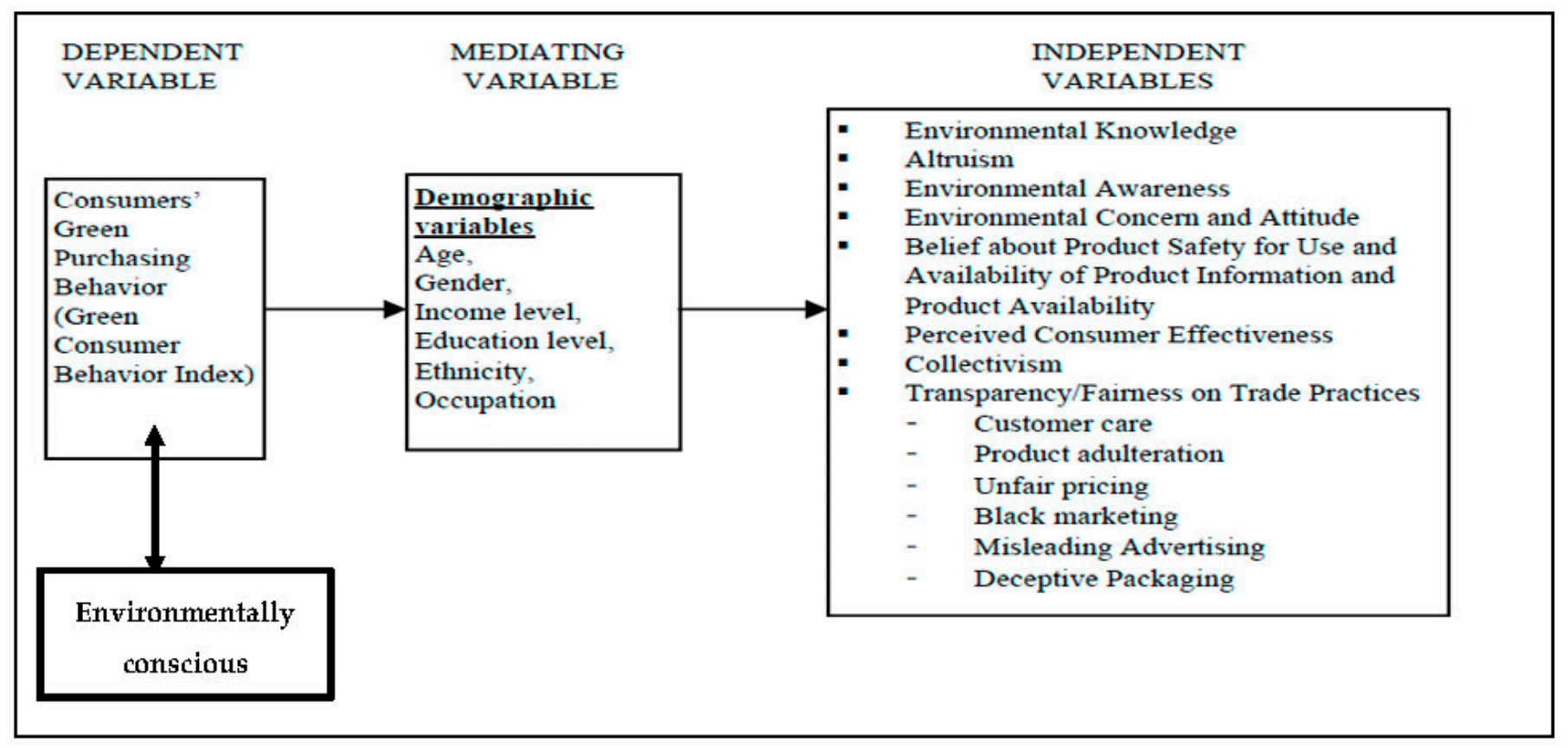

Figure 1. Framework of the determinants of supply and demand of green entrepreneurship, adopted from [55].

\subsection{Description and Justification of Variables}

The dependent variable was the "environmental consciousness of entrepreneurs in Ghana", created as a two-outcome dummy variable out of two environmentally sensitive questions asked during the Global Entrepreneurship Monitor (GEM) 2013 survey in Ghana:

- Entrepreneurs who agreed or strongly agreed that the first factor they consider or will consider before starting any enterprise is its environmental friendliness.

- Entrepreneurs who agreed or strongly agreed that they will not engage in an enterprise that will harm the environment.

These entrepreneurs assumed the value of one (1) while those who disagreed assumed the value of zero (0).

With reference to the conceptual framework discussed in the preceding subsection, mediating demographic variables such as gender (male/female), age category (youth/adults), educational level completed (low level of education - pre-primary to primary education; fairly educated-lower secondary to post-secondary non-tertiary education; high level of education-first stage to second stage of tertiary education) and locality of entrepreneur (rural/urban) have been interacted with entrepreneur types (nascent/owner-manager) as independent variables. Other independent variables considered in the paper include the competitiveness of the products traded by the entrepreneurs and the growth prospects of the enterprise, measured by their perceptions of the number of employees they envisage to have in five years' time, in which case five (5) or more employees are regarded as growth prospect.

\subsection{Description of Data Used for the Study}

This paper used the 2013 GEM dataset for Ghana, especially the aspect that focuses on youth entrepreneurs. The GEM research project is one of the world's leading research consortia since 1997, focusing on improving understanding on entrepreneurship and its relationship to national development. Between 2010 and 2013, about 13 Sub-Saharan African (SSA) countries including Ghana took part in the GEM surveys. The key indicators of GEM are measured through an Adult Population Survey (APS) and the Youth Population Survey (YPS). In 2012 and 2013, the different countries' research teams interviewed between 2000 and 10,000 respondents using a standardized questionnaire provided by the GEM Global Data Team. 


\subsection{The Sample Frame for the 2013 GEM Survey in Ghana}

The 2013 GEM study in Ghana sampled 2100 individuals aged between 18 and 64 years and living in identifiable residential premises as defined by the Ghana Statistical Service (GSS). Except for age, no other demographic variable was used as a basis for selection and therefore, such variables as race, religion and sex were random and determined at the point of interview. In order to ensure that the sampled 2100 individuals were nationally representative, a multi-stage stratified sampling design was used. The first stage of stratification involved splitting the population based on the region of residence, and the desired sample size of 2100 individuals was allocated among the ten regions in Ghana in proportion to their respective populations, as exists within the Ghana Statistical Service (GSS) database. Each region was then divided into districts, which were in turn divided into Census enumeration areas (EAs). About 44 districts, representing a quarter of the total number of districts across Ghana, were randomly selected from the list of districts in each region.

For the sake of uniformity, the decision was made to select a total of 30 individuals from each EA and then weigh the sample appropriately to construct the district, regional and national level estimates. At the household level, houses/dwellings were selected through a systematic random approach using a fixed interval: firstly, the fourth house/dwelling starting from the EA start point was selected, and this approach was replicated after every selected house/dwelling.

\subsection{Model Specification}

The dependent variable (the environmental consciousness of entrepreneurs in Ghana) was a dichotomous (binary dummy) variable assuming the value of one (1) if an entrepreneur is environmentally conscious and the value of zero (0) if the entrepreneur is not environmentally conscious. Entrepreneurs' environmental consciousness was therefore modelled as a non-linear function of the set of explanatory variables as:

$$
y_{i}=f\left(x_{i}\right)
$$

where $y_{i}$ is the dependent variable, i.e., the environmental consciousness of entrepreneurs in Ghana, and $x_{i}$ is the vector of explanatory variables, which include the entrepreneur type; gender; locality; education; age (young/adult); growth prospects; competitiveness of products; and interactive variables. The conditional probability for sampling entrepreneurs who are environmentally conscious is given as:

$$
\pi_{i} \equiv \operatorname{Pr}(Y i) \equiv \operatorname{Pr}\left(Y=1 / X=x_{i}\right)
$$

Clearly, Equation (2) is a non-linear equation with a binary dependent variable where (1) represents entrepreneurs who are environmentally conscious and (0) represents otherwise. This non-linearity form breaks multiple assumptions necessary for the use of the simple ordinary least square techniques, hence, an appropriate technique based on the binary form of the dependent variable is a logistic regression. The probability function (Equation (2)) is thus transformed to assume a general logistic distribution form. The average outcome or the expectation of the group of entrepreneurs who are environmental conscious is estimated as:

$$
E\left(\frac{Y}{x_{i}}\right)=\pi_{i}(1)+\left(1-\pi_{i}\right)(0)=\pi_{i}
$$

Linearizing Equation (3) entails transforming the probability into a form that removes the restrictions on the range of values of the $\pi_{i}$, i.e., between 0 and 1 . This is usually done in two steps: 
Step one transforms the probability form $\left(\pi_{i}\right)$ to the odds that give the ratio of favorable to unfavorable cases. In other words, this gives the ratio of environmentally conscious entrepreneurs to non-environmentally conscious ones, specified in Equation (4) as:

$$
\text { odds }_{i}=\frac{\pi_{i}}{1-\pi_{i}}
$$

Step two entails taking logarithms of Equation (4), which removes the floor restriction on the ranges of values of the dependent variable [58], specified in Equation (5) as:

$$
\mathfrak{y}_{i}=\operatorname{logit}\left(\pi_{i}\right)=\log \left(\frac{\pi_{i}}{1-\pi_{i}}\right)=\beta_{0}+x \beta
$$

Resolving for $\pi_{i}$ in Equation (5) leads to:

$$
\pi_{i}(x ; b)=\frac{e^{\beta_{0}+x \beta}}{1+e^{\beta_{0}+x \beta}}=\frac{1}{1+e^{-\left(\beta_{0}+x \beta\right)}}
$$

Equation (6) can be re-stated in general logistic distribution form as:

$$
\operatorname{Prob}\left(y_{i}=1 \mid x_{i}\right)=\frac{e^{x^{\prime} \beta}}{1+e^{x^{\prime} \beta}}
$$

Based on this general logistic distribution, multiple empirical models have been estimated using different combinations of the explanatory variables as follows:

$$
\begin{array}{ll}
\text { M1: } & y_{i}=\beta_{0}+\beta_{1} \text { Entype }_{i}+\beta_{2} \text { Gender }_{i}+\beta_{3} \text { Gender\#Entype }_{i}+\varepsilon_{i} \\
\text { M2: } & y_{i}=\beta_{0}+\beta_{1} \text { Entype }_{i}+\beta_{2} \text { Locality }_{i}+\beta_{3} \text { Locality\#Entype }_{i}+\varepsilon_{i} \\
\text { M3: } & y_{i}=\beta_{0}+\beta_{1} \text { Entype }_{i}+\beta_{2} \text { Education }_{i}+\beta_{3} \text { Education\#Entype }_{i}+\varepsilon_{i} \\
\text { M4: } & y_{i}=\beta_{0}+\beta_{1} \text { Entype }_{i}+\beta_{2} \text { YouthAdults }_{i}+\beta_{3} \text { YouthAdults\#Entype }_{i}+\varepsilon_{i} \\
\text { M5: } & y_{i}=\beta_{0}+\beta_{1} \text { Entype }_{i}+\beta_{2} \text { Growth }_{i}+\beta_{3} \text { Growth\#Entype }_{i}+\varepsilon_{i} \\
\text { M6: } & y_{i}=\beta_{0}+\beta_{1} \text { Entype }_{i}+\beta_{2} \text { Competitiveness }_{i}+\beta_{3} \text { Competitiveness\#Entype }_{i}+\varepsilon_{i} \\
\text { M7: } & y_{i}=\beta_{0}+\beta_{1} \text { Education }_{i}+\beta_{2} \text { YouthAdults }_{i}+\beta_{3} \text { Education\#YouthAdults }_{i}+\varepsilon_{i}
\end{array}
$$

Model 1 includes entrepreneur type (measured dichotomously as owner-manager and nascent entrepreneur), gender and an interactive term of gender and entrepreneur type as the dependent and mediating variables. Model 2 includes entrepreneur type, locality (entrepreneur operating in a rural or urban setting) and their interactive term as explanatory variables. Model 3 estimates the variation in the dependent variable (y), explained by the entrepreneur type, the education level completed by entrepreneur (measured in 3 categories: no education, fairly educated and higher level of education) and their interactive term. Model 4 combines entrepreneur type with the age category (youth/adult) of the entrepreneur and their interactive term as the independent and mediating variables. The youth are aged 18-35 while the adults are aged 36-60. Model 5 combines entrepreneur type with the growth prospects of the entrepreneur (measured as perceived growth prospects of the enterprise in the next 5 years) and the interactive term as the explanatory variables. Model 6 estimates how entrepreneur type, the competitiveness of the product and their interactive term explain variation in the dependent variable, while Model 7 combines the education level completed by the entrepreneur with their age category, and their interactive term as explanatory variables.

The purpose of estimating all these models was to assess the impacts of different interactions of variables on the decision of entrepreneurs in Ghana to be environmentally conscious or not. These variable combinations were purely driven by the researchers' quest to better understand the factors that influence the environmental consciousness of entrepreneurs in Ghana distinctively, based on the variables captured in the 2013 GEM dataset. This decision limits the number of explanatory variables included in each model so that their explanatory and predictive powers can be better understood rather than including 
many variables, a situation whereby the predictive power of one variable depends on the imaginary assumption that all the other variables are constant.

\subsection{Qualitative Data and Analytical Method}

The paper also explored other factors in the conceptual framework that motivates eco-preneurs, but have not been captured in the quantitative 2013 GEM data. This exploration was done through qualitative data collected from six (6) randomly selected entrepreneurs from three regions, Greater Accra, Ashanti and Volta Regions, who have clear entrepreneurial intentions or actively engaged in an entrepreneurial activity. Though the respondents were randomly selected, the most important selection criterion was their willingness to participate as there were a number of recorded rejections. Four of the samples were owner-manager entrepreneurs while two were nascent entrepreneurs. These regions have the highest entrepreneurial activity rates in Ghana with appreciable varieties as well. Therefore, the researchers chose to conveniently interview six entrepreneurs from these regions about factors that inspire them to be environmentally conscious. Observations from the six participants were sufficient for the exploratory research once they provided enough evidence to saturate the inquiry [59]. Relevant quotes, representing the views of the participants were broadly generated using first and second cycle coding methods, which were subsequently subjected to content analysis.

\section{Results and Discussions}

The logistic regression results of the model specified in the preceding section are presented in Table 2 below. The study estimated seven (7) different logistic models (equations) involving different combinations of explanatory variables informed by the conceptual framework discussed above. Some of the variables were interacted to assess their impacts on environmental consciousness of entrepreneurs in Ghana. Generally, all the models exhibited fitness with a minimum observation of 1040 entrepreneurs. The Wald chi2, which shows general overall joint significance of the explanatory variables, were strongly significant in all cases (models) with probabilities less than 0.05 , as shown in Table 2. All, except the interaction of locality and entrepreneur type, were significant either at $1 \%, 5 \%$ or $10 \%$.

Table 2. Logistic regression results (odds ratio).

\begin{tabular}{|c|c|c|c|c|c|c|c|}
\hline \multirow{2}{*}{ Explanatory Variables } & \multicolumn{7}{|c|}{$\begin{array}{l}\text { Odds Ratios and Standard Errors of the Different Logistic Regression Models (with } \\
\text { Environmental Consciousness of Entrepreneurs }{ }^{\text {a }} \text { as the Dependent Variable) }\end{array}$} \\
\hline & (1) & (2) & (3) & (4) & (5) & (6) & (7) \\
\hline \multicolumn{8}{|l|}{ Entrepreneur type ${ }^{b}$} \\
\hline Owner-manager & $\begin{array}{l}2.63^{* * *} \\
(0.26)\end{array}$ & $\begin{array}{l}2.21 * * * \\
(0.19)\end{array}$ & $\begin{array}{l}2.22 * * * \\
(0.24)\end{array}$ & $\begin{array}{l}2.30 * * * \\
(0.22)\end{array}$ & $\begin{array}{l}3.82 * * * \\
(0.38)\end{array}$ & $\begin{array}{l}3.08^{* * *} \\
(1.02)\end{array}$ & \\
\hline \multicolumn{8}{|l|}{ Gender $^{c}$} \\
\hline Female & $\begin{array}{l}2.52 * * * \\
(0.62)\end{array}$ & & & & & & \\
\hline \multicolumn{8}{|l|}{ Locality $^{\mathrm{d}}$} \\
\hline Rural & & $\begin{array}{l}2.91 * * * \\
(1.02)\end{array}$ & & & & & \\
\hline \multicolumn{8}{|l|}{ Education $^{\mathrm{e}}$} \\
\hline Fairly educated & & & $\begin{array}{l}2.09 * * * \\
(0.45)\end{array}$ & & & & $\begin{array}{l}2.22 * * * \\
(0.25)\end{array}$ \\
\hline High level of education & & & $\begin{array}{l}4.33^{* *} \\
(2.78)\end{array}$ & & & & $\begin{array}{l}3.2^{* * *} \\
(1.16)\end{array}$ \\
\hline \multicolumn{8}{|l|}{ Youth/adults ${ }^{f}$} \\
\hline Adults & & & & $\begin{array}{c}7.86^{* * *} \\
(3.15)\end{array}$ & & & $\begin{array}{c}2.67^{* * *} \\
(0.37)\end{array}$ \\
\hline
\end{tabular}


Table 2. Cont.

\section{Explanatory Variables}

Growth prospect $\mathrm{g}$

Growth in 5 years

Competitiveness of products ${ }^{h}$

Competitive products

(0.70)

Gender\#Entrep_type

\begin{tabular}{cc}
\hline Female\#Owner-manager & $0.40^{* * *}$ \\
& $(0.11)$
\end{tabular}

Locality\#Entrep_type

Rural\#Owner-manager

(0.20)

Education\#Entrep_type

Fairly_edu\#Owner-manager

0.65 *

(0.17)

0.30 *

High_edu\#Owner-manager

Youth_adults\#Entrep_type

Adults\#Owner-manager

(0.07)

Grwoth_prosp\#Entrep_type

Growth_pros\#Owner-manager

Competition\# Entrep_type

Competitive\#Owner-manager

Education\#Youth_Adults

Fairly Educated\#Adults

Highly Educated\#Adults

\begin{tabular}{lcccccccc}
\hline No. of obs. & 1245 & 1245 & 1235 & 1245 & 1245 & 1040 & 1235 \\
\hline Wald chi2 & 216.74 & 215.5 & 222.16 & 230.44 & 229.25 & 236.32 & 218.03 \\
\hline Prob $>$ chi2 & 0.00 & 0.00 & 0.00 & 0.00 & 0.00 & 0.00 & 0.00 \\
\hline
\end{tabular}

\section{Reference categories}

a

b

$\begin{array}{ll}\text { d } & \text { Male } \\ \text { Urban }\end{array}$

scious

Nascent uncon-

en- $\quad f \quad$ Youth

Urban $\quad \mathrm{h}$
Low education level

No growth prospects in 5 years

Products uncompetitive 


\subsection{Demographics vis-à-vis Entrepreneur Type}

Model one, captured in column (1) in Table 2, assessed the impacts of entrepreneur type and gender with their interactive impact on the environmental consciousness of entrepreneurs in Ghana. With reference to male entrepreneurs, the odds of an ownermanager entrepreneur being environmentally conscious were estimated at 2.63 . This means the odds of an owner-manager entrepreneur being environmentally conscious are $163 \%$ higher than the odds of a nascent entrepreneur becoming an eco-preneur.

In terms of gender, the odds of female entrepreneurs being environmentally conscious are $152 \%$ higher than the odds of male entrepreneurs being environmentally conscious. With the gender variable interacting with the entrepreneur type, the odds of female owner entrepreneurs being environmentally conscious are $60 \%$ lower than the odds of female nascent entrepreneurs becoming eco-preneurs. In other words, females who intend to become entrepreneurs are more likely to be environmentally conscious compared to females who are owner-managers. Entrepreneur type and gender statistically determine the environmental consciousness of entrepreneurs as they are statistically significant at $1 \%$. As shown in the interactive term, potential (nascent) female entrepreneurs are more likely to become eco-preneurs. This means that as new entrants pursue sustainability opportunities, the existing businesses may respond in an equal or higher measure to remain competitive as suggested by [50]. This could explain the higher odds of male owner-manager entrepreneurs over their nascent entrepreneurs.

Model two, presented in column (2) in Table 2, investigated the impacts of entrepreneur type and locality with their interactive term on environmental consciousness of entrepreneurs in Ghana. Similarly to model one, the odds of an owner-manager being environmentally conscious are $121 \%$ higher than the odds of nascent entrepreneurs being environmentally conscious. In terms of location, entrepreneurs in the rural areas have $191 \%$ more odds of being environmentally conscious than entrepreneurs in the urban areas. Businesses in the rural areas have been viewed as less polluting and more environmentally concerned. This corroborates the assertion by [14] that Ghanaian cities, particularly Accra, are engulfed in filth, partly due to business activities. When the location variable was interacted with entrepreneur types, nascent entrepreneurs in rural areas were found to have higher odds of becoming eco-preneurs compared to existing business owners in the rural areas. From the statistical results, location statistically influences eco-preneurship as suggested by [54].

The impacts of educational levels completed by entrepreneurs and entrepreneur types on the environmental consciousness of entrepreneurs in Ghana are presented by model three in column (3) in Table 2. In relation to low educational level attainment (i.e., preprimary to primary education), entrepreneur type had similar effects as in models one and two. The odds for entrepreneurs who completed lower secondary to post-secondary nontertiary education are $109 \%$ higher than entrepreneurs who only completed pre-primary to primary education. Also, the odds of entrepreneurs who completed the first stage to second stage of tertiary education are 333\% higher than entrepreneurs who only completed pre-primary to primary education. From these results, education significantly influences the environmental consciousness of entrepreneurs in Ghana as entrepreneurs who attained higher levels of education tended to be environmentally sensitive and corroborate the work of [47-49]. The interactive term shows that, for those with higher levels of education, potential entrepreneurs are more likely to become eco-preneurs compared to existing owners.

Model four, presented in column (4), estimated the impacts of age category (youth/adults) and entrepreneur type with their interactive term on environmental consciousness of entrepreneurs in Ghana. The impact of entrepreneur type was similar to the impacts in the earlier discussed models. In terms of the age category, the odds of an adult entrepreneur being environmentally conscious are $686 \%$ higher than the odds of a youth entrepreneur being environmentally conscious. More often than not, the youthful population tended to be less considerate of the environment in their relentless pursuit of success and profit, which is reflected in the results. The interactive term showed that 
adult potential entrepreneurs are far more likely to be environmentally conscious than the existing adult entrepreneurs. These variables were statistically significant at $1 \%$.

The educational levels attained and age category (youth/adult) were combined in model seven (column (7)) in Table 2. Just like in model three, entrepreneurs with higher education levels were more concerned about the environment than those with low education levels. Also, model seven showed that adult entrepreneurs are more concerned about the environment than their youth counterparts. The interactive term, however, showed that as the youth receive higher education, they tend to be more environmentally conscious. These variables are statistically significant, implying that education levels and age category significantly influence eco-preneurship in Ghana. Education contributes to an individual's knowledge and skill acquisition, self-confidence, positive self-motivation and sustainability orientation, which was found by [47-49] to affect eco-preneurship.

\subsection{Growth Prospects and Competitiveness of Traded Products vis-à-vis Entrepreneur Type}

Model five estimates the impacts of growth prospects of entrepreneurs and entrepreneur types vis-à-vis the environmental consciousness in Ghana. Akin to the other models, the odds of an owner-manager entrepreneur being environmentally conscious are $282 \%$ higher than the odds of a nascent entrepreneur being environmentally conscious. The odds of entrepreneurs with positive growth prospects in the next 5 years being environmentally conscious is $119 \%$ higher than the odds of entrepreneurs who do not envisage to grow in the next 5 years. Growth expectations encourage entrepreneurs to pursue sustainability in their activities in order to meet the growing demands and expectations of consumers whose tastes and preferences are evolving towards sustainability. In other words, growth prospects of businesses foster environmental friendliness. In terms of the growth prospect and entrepreneur type interactive impact, potential entrepreneurs with growth prospects are more likely to become eco-preneurs. The significant results showed that growth prospect of a business highly influences the environmental consciousness of the entrepreneur.

Model six, represented in column (6), estimated the impacts of the competitive nature of traded products and services as well as entrepreneur types relative to their environmental consciousness in Ghana. The impact of entrepreneurship type was similar to the impacts in the other six models. The odds of entrepreneurs dealing in competitive products being environmentally conscious are $150 \%$ higher than the odds of entrepreneurs dealing in uncompetitive products and services. Healthy competition faced by goods and services produced by entrepreneurs implies that activity and product differentiation is key to attracting sizeable customer bases in order to optimize sales. In terms of the interactive term, nascent entrepreneurs with competitive spirits are even more likely to become eco-preneurs compared to existing business owners dealing in competitive products and services. These variables are statistically significant, implying that dealing in competitive products and services does influence the environmental consciousness of entrepreneurs in Ghana.

\subsection{Other Perceived Motivating Factors of Eco-Preneurship in Ghana}

The environmental knowledge and awareness predisposition of the entrepreneur highly motivate them to be more concerned about the possible harm their actions and inactions could cause to their overall business environment. It could easily be deduced from the views of the in-depth interview participants that their prior knowledge of the health benefits of a clean environment has caused them to be more environmentally conscious as they go about their business activities. One female owner-manger entrepreneur from Obuasi in the Ashanti Region voiced that:

"... as a human being, if you take care of your immediate environment where you live and work, it prevents you from contracting all kinds of sanitation related diseases".

Affirmatively, a male owner-manager entrepreneur from the same town said: 
"... I am very mindful of environmental issues concerning my business because I put my customers and myself at health risk, if I pollute my environment with my business activities".

These views of the owner-manager entrepreneurs from the Ashanti Region are very representative of the other owner-mangers and nascent entrepreneurs sampled for this study. According to a male nascent entrepreneur from the Greater Accra Region:

"... for me personally, environmental sustainability is something I hold very high and consider very important in everything we do".

Not only does this view emphasize prior positive environmental knowledge, but also indicates the fact that entrepreneurs in Ghana generally consider environmental sustainability to be an important element to their business success.

However, a male nascent entrepreneur in the Greater Accra Region noted that factors such as " ... government's incentive packages for eco-preneurs, enforcement of green business regulations, rewards for eco-preneurs, awareness creation and education packages from government and non-government organizations" could motivate entrepreneurs to be more environmentally conscious. Nevertheless, the lack of these factors do little to stop entrepreneurs who are environmentally concerned with their business activities from becoming eco-preneurs. According to a female owner-manager entrepreneur from Obuasi in the Ashanti Region:

"... I just feel personally that it is good to be environmentally conscious, to do things that would not harm the environment".

Sharing a similar view, a nascent entrepreneur from the Greater Accra Region said that:

"... to use less of the paper things, the plastic things, to create less waste. We are really hoping that wherever we go it will be part of our practice, to be less polluting to the environment. So, it is purely on personal level. We just feel it is good to be conscious of how we degrade the environment".

Due to personal decisions such as these, the eco-preneurs are indulging in (or thinking of indulging, in terms of nascent entrepreneurs) such green practices as soft electronic communication channels that use less paper, environmentally friendly building materials, observing efficiency practices at the workplace, keeping the surroundings of the business clean and efficiently disposing of waste. According to a male owner-manager entrepreneur in the Greater Accra Region:

"... all the time the stuff come in boxes, so we are always taking boxes and throwing them outside. So, anytime we find that there are empty boxes, either we burn them, or we give them out for collectors for recycling. So that's how we do it".

A male nascent entrepreneur in the Greater Accra Region also pointed out that:

"... as I mentioned, things like these environmental issues are things we have considered very well before going into what we want to do ... Even in our offices, we want to go with less paper, and use more of things that we can do on the machines".

Most of the eco-preneurs perceive these environmentally conscious actions as attracting more potential customers for their businesses. The views of a female owner-manager entrepreneur in Obuasi in the Ashanti Region gave testament to that:

"... I burnt what had to be burnt and disposed of those things which I didn't need. I did all that so that once I began working, I would draw a lot of customers to my shop".

\section{Conclusions}

The total entrepreneurial activity rate is high in Ghana where unregulated and informal low-profit businesses are very common and operate unsustainably. Little has been studied or understood about factors that motivate or demotivate entrepreneurs to be more sensitive to the environment where they produce and distribute their products and services. This paper set out to fill the literature gap by investigating the impacts of 
demographic characteristics of entrepreneurs relative to the environmental consciousness of entrepreneurs in Ghana. Other factors that were investigated include the entrepreneur type, growth prospect of the entrepreneur as well as the competition faced by products traded by entrepreneurs in Ghana. In using logistic regression techniques in estimating seven different models involving different combinations of variables, it is evident that owner-manager entrepreneurs often become environmentally conscious while potential entrepreneurs have the intention at the very least, or enter the business market before taking advantage of sustainability opportunities. Female entrepreneurs and entrepreneurs operating in rural localities in Ghana tend to be more environmentally conscious than male and urban entrepreneurs. Education fosters environmental awareness and consciousness as the evidence shows that entrepreneurs with higher education are more environmentally conscious than those who only completed pre-primary and primary education. Adults are found to be more environmentally concerned than their youth counterparts and entrepreneurs who have growth prospects in the next 5 years are equally environmentally conscious. Additionally, entrepreneurs trading in competitive products are more likely to be environmentally conscious than those trading in uncompetitive products. The qualitative data also identified prior knowledge of the environment and general concerns for the environment to be key motivating factors for entrepreneurs to be more environmentally conscious even in the face of limited external supports.

It can be concluded that the sensitivity of entrepreneurs to their environment in Ghana ultimately depends on the entrepreneurs. The type of entrepreneur informs their decision in being environmentally sensitive or not. Entrepreneurs who have established businesses active for years tend to be more concerned about the environment compared to those who have just started, as they usually prioritize the growth of their businesses. Additionally, trading in competitive products/services with future growth prospects that lead to competition for customers informs environmental awareness. However, how learned the entrepreneur is, with prior knowledge of the environment, cannot be discounted. With little empirical knowledge about this subject in Ghana, this study is a significant addition to knowledge in the field even though it used a dataset that is slightly dated and did not have several of the independent variables explained in the theoretical framework. The findings nonetheless have implications for policy actions on green entrepreneurship development in Ghana. They call for the need to embark on educational campaigns to promote the adherence to environmental regulations by all businesses, especially those in urban area trading in competitive products, to enhance green entrepreneurship development in the country. The effective enforcement of environmental laws and regulation by the appropriate enforcement agencies, such as the Environmental Protection Agency and Environmental Units at the local government level, could complement the educational campaigns, in order to build a robust eco-preneurship landscape in Ghana.

Author Contributions: Conceptualization, S.B. and I.S.K.A.; methodology, S.B. and I.S.K.A.; software and data analysis, I.S.K.A.; validation, S.B.; writing-original draft preparation, I.S.K.A.; writingreview and editing, S.B.; writing-preparation of final draft, I.S.K.A.; supervision, S.B. All authors have read and agreed to the published version of the manuscript.

Funding: Data collection for the 2013 Ghana GEM study was funded by International Development Research Centre (IDRC), Canada. The authors are therefore grateful for having access to use the data.

Institutional Review Board Statement: The study was conducted according to the guidelines of the Declaration of Helsinki, and approved by the Institutional Review Board of Council for Scientific and Industrial Research (CSIR), Ghana (protocol code: RPN.004/CSIR-IRB/2012 on 25 April 2012).

Informed Consent Statement: Informed consent was obtained verbally from all subjects involved in the study. 
Data Availability Statement: Ghana was part of the Global Entrepreneurship Monitor (GEM) consortium in 2013, and the Institute of Statistical, Social and Economic Research (ISSER) was the consortium partner. Consequently, the ISSER has the dataset for this round of survey. An output of this dataset is in the abridged Ghana Youth Report online: https: / www.gemconsortium.org/ economy-profiles/ghana (accessed on 14 August 2021).

Conflicts of Interest: The authors declare no conflict of interest. The funders had no role in the design of the study; in the collection, analyses, or interpretation of data; in the writing of the manuscript; or in the decision to publish the results.

\section{References}

1. Hall, J.K.; Daneke, G.A.; Lenox, M.J. Sustainable development and entrepreneurship: Past contributions and future directions. J. Bus. Ventur. 2010, 25, 439-448. [CrossRef]

2. Muo, I.; Azeez, A.A. Green Entrepreneurship: Literature Review and Agenda for Future Research. Int. J. Entrep. Knowl. 2019, 7, 17-29. [CrossRef]

3. Dyllick, T.; Muff, K. Clarifying the Meaning of Sustainable Business. Organ. Environ. 2016, 29, 156-174. [CrossRef]

4. Gifford, D., Jr. The value of going green. Harv. Bus. Rev. 1997, 75, 11-13.

5. Hart, S.L. Beyond greening: Strategies for a sustainable world. Harv. Bus. Rev. 1997, 75, 66-77.

6. Mudd, G.M. Global trends in gold mining: Towards quantifying environmental and resource sustainability. Resour. Policy 2007, 32, 42-56. [CrossRef]

7. Dadzie, D.K.; Kaliluthin, A.K.; Kumar, D.R. Exploration of waste plastic bottles use in construction. Civ. Eng. J. 2020, 6, 2262-2272. [CrossRef]

8. Allen, J.C.; Malin, S. Green entrepreneurship: A method for managing natural resources? Soc. Nat. Resour. 2008, 21, 828-844. [CrossRef]

9. Shane, S.A. Academic Entrepreneurship: University Spinoffs and Wealth Creation; Edward Elgar Publishing: Cheltenham, UK, 2004.

10. Adrien, M.H.; Kirouac, S.; Sliwinski, A. Women's entrepreneurship in Canada: All that glitters is not gold. Univers. Occas. Pap. 1999, 38, 1-13.

11. Robichaud, Y.; LeBrasseur, R.; Nagarajan, K.V. Necessity and Opportunity-Driven Entrepreneurs in Canada: An Investigation into Their Characteristics and an Appraisal of the Role of Gender. Available online: http:/ /m.www.na-businesspress.com/JABE/ Jabe111/RobichaudWeb.pdf (accessed on 16 March 2019).

12. Kritikos, A.S. Entrepreneurs and their impact on jobs and economic growth. IZA World Labor 2014, 8, 1-10. [CrossRef]

13. Herrington, M.; Kelley, D. African Entrepreneurship: Sub-Saharan African Regional Report; International Development Research Centre: Ottawa, ON, Canada, 2012; pp. 1-74.

14. Obour, S.K. Accra Sinks under Filth. The Mirror, 15 September 2012; p. 24.

15. GSS. Ghana Living Standards Survey round 7 (GLSS7), Main Report, 2019. In Ghana Statistical Service. Available online: https://statsghana.gov.gh/gsspublications.php?category=MTAwMjg3Mzk3NC4zMDc=/ebstats/1opr93rn57 (accessed on 23 February 2020).

16. Aning, K.G. The Structure and Importance of the Commercial and Village Based Poultry in Ghana, Final Review Report; Food and Agriculture Organization of United Nations: Rome, Italy, 2006.

17. Essegbey, G.O. Agribusiness Innovation Study_-The Ghana Experience; Science and Technology Policy Research Institute (STEPRICSIR): Accra, Ghana, 2008.

18. Jabik, B.; Bawakyillenuo, S. Green entrepreneurship for sustainable development in Ghana: A review. Ghana Soc. Sci. 2016, 13, 96.

19. Tandoh-Offin, P. A Review of Environmental Entrepreneurship as an Agenda for Rural Development: The Case for Ghana. J. Afr. Stud. Dev. 2010, 2, 27-34. [CrossRef]

20. Schaper, M. The essence of ecopreneurship. Greener Manag. Int. 2002, 38, 26-30. [CrossRef]

21. Parrish, B.D. Sustainability-driven entrepreneurship: Principles of organization design. J. Bus. Ventur. 2010, $25,510-523$. [CrossRef]

22. Tilley, F.; Young, W. Sustainable Entreprenuers: Are they the true wealth generators of the future? Greener Manag. Int. 2009, 55, 79-92.

23. Dixon, S.E.; Clifford, A. Ecopreneurship-A new approach to managing the triple bottom line. J. Organ. Chang. Manag. 2007, 20, 326-345. [CrossRef]

24. Isaak, R. The Making of the Ecopreneurs; Greenleaf Publishing, Pace University: New York, NY, USA, 2002.

25. Taylor, D.W.; Walley, E.E. The green entrepreneur: Opportunist, maverick or visionary? Int. J. Entrep. Small Bus. 2004, 1, 56-69. [CrossRef]

26. Dean, T.J.; McMullen, J.S. Toward a theory of sustainable entrepreneurship: Reducing environmental degradation through entrepreneurial action. J. Bus. Ventur. 2007, 22, 50-76. [CrossRef]

27. WCED. World commission on environment and development. Our Common Future 1987, 17, 1-91.

28. Zhaojun, Y.; Jun, S.; Yali, Z.; Ying, W. Green, Green, It's Green: A Triad Model of Technology, Culture, and Innovation for Corporate Sustainability. Sustainability 2017, 9, 1369. 
29. Ball, C.; Kittler, M. Removing environmental market failure through support mechanisms: Insights from green start-ups in the British, French and German energy sectors. J. Small Bus. Econ. 2017, 2, 831-844. [CrossRef]

30. Malavisi, A. The Urgency of the Greening of Ethics. Australas. J. Log. 2018, 4, 593-609.

31. Dale, G. Climate, communism and the age of affluence? In A Review of Aaron Bastani in Automated Luxury Communism: A Manifesto; Ecologist: Bideford, UK, 2019; pp. 1-6.

32. Yousuf, N.A.; Awang, H.; Iranmaneseh, M. Determinants and outcome of environmental practices in Malaysian construction projects. J. Clean. Prod. 2017, 156, 345-354. [CrossRef]

33. O'Neill, K.; Gibbs, D. Rethinking green entrepreneurship-Fluid narratives of the green economy. J. Environ. Plan. 2016, 48, 1727-1749. [CrossRef]

34. Nikolaou, E.I.; Ierapetritis, D.; Tsagarakis, K.P. An evaluation of the prospects of green entrepreneurship development using a SWOT analysis. Int. J. Sustain. Dev. World Ecol. 2011, 18, 1-16. [CrossRef]

35. Anderson, T.L.; Leal, D. Free Market Environmentalism: Revised Edition; St. Martin's Press: New York, NY, USA, 2001.

36. York, J.G.; Venkataraman, S. The entrepreneur-environment nexus: Uncertainty, innovation, and allocation. J. Bus. Ventur. 2010, 25, 449-463. [CrossRef]

37. Volery, T. Ecopreneurship: Rationale, current issues and future challenges. In Conference Paper of Swiss Research Institute of Small Business and Entrepreneurship; University of St. Gallen: St. Gallen, Switzerland, 2002; pp. 541-553.

38. Keogh, P.D.; Polonsky, M.J. Environmental commitment: A basis for environmental entrepreneurship? J. Organ. Chang. Manag. 1998, 11, 38-49. [CrossRef]

39. Krueger, N., Jr. Encouraging the Identification of Environmental Opportunities. J. Organ. Chang. Manag. 1998, 11, 174-183. [CrossRef]

40. Hillary, R. Small and Medium-Sized Enterprises and the Environment; Greenleaf: Sheffield, UK, 2000.

41. Porter, M.E.; Van der Linde, C. Toward a new conception of the environment competitiveness relationship. J. Econ. Perspect. 1995, 9, 97-118. [CrossRef]

42. Anderson, A. Cultivating the garden of Eden: Environmental entrepreneuring. J. Organ. Chang. Manag. 1998, 11, 135-144. [CrossRef]

43. Lenox, M.; York, J.G. Environmental entrepreneurship. In The Oxford Handbook of Business and Natural Environment; OUP Oxford: Oxford, UK, 2011; pp. 70-92.

44. Nuringsih, K.; Puspitowati, I. Determinants of eco entrepreneurial intention among students: Study in the entrepreneurial education practices. Adv. Sci. Lett. 2017, 23, 7281-7284. [CrossRef]

45. Busenitz, L.W.; Gomez, C.; Spencer, J.W. Country institutional profiles: Unlocking entrepreneurial phenomena. Acad. Manag. J. 2000, 43, 994-1003.

46. Larson, A.L. Sustainable innovation through an entrepreneurship lens. Bus. Strategy Environ. 2000, 9, 304-317. [CrossRef]

47. Pandrani, M.D.; Ferguson, D. Enabling Factors of Green Entrepreneurship: A case study of organic agriculture produce in the Sindh and Balochistan provinces of Pakistan. Entrep. Learn. 2013, 3, 181-190. Available online: https://hrcak.srce.hr/file/192539 (accessed on 16 March 2019).

48. Ye, Q.; Zhou, R.; Anwar, M.A.; Siddiquei, A.N.; Asmi, F. Entrepreneurs and environmental sustainability in the digital era: Regional and institutional perspectives. Int. J. Environ. Res. Public Health 2020, 17, 1355. [CrossRef]

49. Kuckertz, A.; Wagner, M. The influence of sustainability orientation on entrepreneurial intentions-Investigating the role of business experience. J. Bus. Ventur. 2010, 25, 524-539. [CrossRef]

50. Hockerts, K.; Wüstenhagen, R. Greening Goliaths versus emerging Davids Theorizing about the role of incumbents and new entrants in sustainable entrepreneurship. J. Bus. Ventur. 2010, 25, 481-492. [CrossRef]

51. Pacheco, D.F.; Dean, T.J.; Payne, D.S. Escaping the green prison: Entrepreneurship and the creation of opportunities for sustainable development. J. Bus. Ventur. 2010, 25, 464-480. [CrossRef]

52. Meek, W.R.; Pacheco, D.F.; York, J.G. The impact of social norms on entrepreneurial action: Evidence from the environmental entrepreneurship context. J. Bus. Ventur. 2010, 25, 493-509. [CrossRef]

53. Muhamad, M.; Anuge, J. Exploring the challenge for Sustainable Development in the energy sector: Sociomaterial view of two British and Nigerian cases. In Proceedings of the World Association for Sustainable Development (WASD) 14th International Annual Conference, London, UK, 20-22 July 2016; pp. 2-14.

54. Hassan, R.A.; Nordin, R. Key Determinants of Green Entrepreneurship among SMEs in Malaysia. In Proceedings of the 33rd International Business Research Conference, Dubai, United Arab Emirates, 4-5 January 2016.

55. Kaufmann, H.R.; Panni, M.F.A.K.; Orphanidou, Y. Factors affecting consumers' green purchasing behavior: An integrated conceptual framework. Amfiteatru Econ. J. 2012, 14, 50-69.

56. Sarigöllü, E. A cross-country exploration of environmental attitudes. Environ. Behav. 2009, 41, 365-386. [CrossRef]

57. Kim, Y.; Choi, S.M. Antecedents of green purchase behavior: An examination of collectivism, environmental concern, and PCE. ACR N. Am. Adv. 2005, 32, 592-599.

58. Galbraith, C.S.; Rodriguez, C.L.; Stiles, C.H. Social capital as a club good: The case of ethnic communities and entrepreneurship. J. Enterprising Communities People Places Glob. Econ. 2007, 1, 38-53. [CrossRef]

59. Creswell, J.W. Five qualitative approaches to inquiry. In Qualitative Inquiry and Research Design: Choosing among Five Approaches; SAGE Publications: Thousand Oaks, CA, USA, 2007; Volume 2, pp. 53-80. 